\title{
MELAWAN STIGMA INFERIORITAS PEREMPUAN: \\ KAJIAN NOVEL MIDAH (SI MANIS BERGIGI EMAS) \\ KARYA PRAMOEDYA ANANTA TOER DAN NOVEL DI BALIK KERLING \\ SAATIRAH KARYA NINIK M. KUNTARTO
}

\author{
Robiatul Adawiyah ${ }^{1)}$ dan Muakibatul Hasanah ${ }^{2)}$ \\ Email: adawiyahrobiatu1003@gmail.com ${ }^{1)}$, muakibatul.hasanah.fs@um.ac.id ${ }^{2}$ \\ Jurusan Sastra Indonesia, Fakultas Sastra, Universitas Negeri Malang
}

\begin{abstract}
Abstrak
Seiring berkembangnya zaman, tradisi yang mengengkang kebebasan kaum perempuan mulai diperjuangkan untuk dihapuskan melalui gerakan feminisme. Penyuaraan hak-hak perempuan tidak hanya dilakukan melalui gerakan-gerakan secara nyata, namun juga dilakukan secara halus dengan memasukkan ideologiideologi feminsime melalui karya sastra. Penelitian ini bertujuan mendeskripsikan bentuk ketidakadilan gender dan bentuk perlawanan perempuan terhadap stigma inferioritas yang selama ini melekat pada diri perempuan. Penelitian ini menggunakan pendekatan kritik sastra feminis. Sumber data penelitian adalah novel Midah (Si Manis Bergigi Emas) karya Pramoedya Ananta Toer dan novel Di Balik Kerling Saatirah karya Ninik M. Kuntarto. Teknik yang digunakan untuk mengumpulkan data-data bentuk feminisme yang ada di dalam kedua novel tersebut adalah dengan membaca kritis dan membaca berkesinambungan. Analisis dilakukan dengan cara (1) kodifikasi data, (2) pengelompokan data, (3) interpretasi makna teks, (4) deskripsi bentuk ketidakadilan gender dan bentuk perlawanan gender, serta (5) penyimpulan hasil analsisis. Hasil penelitian sebagai berikut. Pertama, ketidakadilan gender dialami oleh dua sosok perempuan dalam dua novel berbeda, yaitu Midah dan Saatirah. Midah mendapatkan perlakuan tidak adil dari perjodohan yang dilakukan oleh orangtuanya dan dia juga mendapatkan ketidakadilan dari sosok pria yang menjadikannya budak pemuas nafsu. Saatirah mendapatkan perlakuan tidak adil dalam hubungan rumah tangganya. Kedua, bentuk perlawanan yang dilakukan oleh Midah dan Saatirah adalah dengan berusaha bangkit dari keterpurukan untuk membuktikan eksistensinya dan berusaha memperoleh kebahagian dengan cara yang mereka kehendaki tanpa ada campur tangan dari orang lain.
\end{abstract}

Kata Kunci: stigma, inferioritas, marginal, feminism

\section{AGAINST THE STIGMA OF WOMEN'S INFERIORITY IN MIDAH (SI MANIS BERGIGI EMAS) A NOVEL BY PRAMOEDYA ANANTA TOER AND DI BALIK KERLING SAATIRAH A NOVEL BY NINIK M. KUNTARTO}

\begin{abstract}
Along with the development of the times, struggles for traditions that curb the freedom of women began to be eliminated through the feminism movement.
\end{abstract}


Voicing women's rights is not only done through real movements, but also subtly by incorporating feminine ideologies through literary works. This study aims to describe the form of gender injustice and the form of women's resistance to the inferiority stigma that has been attached to women. This study uses a feminist literary criticism approach. Sources of research data are the novel Midah (Si Manis Bergigi Emas) by Pramoedya Ananta Toer and the novel Di Balik Kerling Saatirah by Ninik M. Kuntarto. The technique used to collect data on the forms of feminism in both novels is critical reading and continuous reading. The analysis was carried out by (1) data codification, (2) data grouping, (3) interpretation of the meaning of the text, (4) descriptions of forms of gender injustice and forms of gender resistance, and (5) concluding the results of the analysis. The research results are as follows. First, gender injustice is experienced by two female figures in two different novels, namely Midah and Saatirah. Midah received unfair treatment from an arranged marriage by her parents and he also received injustice from a male figure who made her a slave to the satisfaction of lust. Saatirah received unfair treatment in her household relationship. Second, the form of resistance carried out by Midah and Saatirah is to try to rise from adversity to prove their existence and try to get happiness in the way they want without interference from others.

Keywords: stigma, inferiority, marginal, feminine

\section{PENDAHULUAN}

Karya sastra merupakan bentuk citraan dari kehidupan nyata yang dituangkan oleh seorang pengarang dalam bentuk tulisan. Meskipun karya sastra bersifat fiksional, di dalamnya tetap termuat nilai-nilai kehidupan, kepercayaan, ideologi, dan budaya dalam kehidupan nyata yang ada dalam lingkungan pengarang. Hal tersebut sesuai dengan pemikiran Endraswara (2008:102) yang menyatakan bahwa karya sastra merupakan ungkapan kejiwaan pengarang yang menggambarkan emosi dan pemikirannya untuk meluapkan isi hati. Oleh sebab itu, biasanya seorang pengarang mengangkat isuisu yang akrab dengan kehidupannya, seperti isu-isu tentang kesenjangan sosial, pertentangan kelas, konflik sosial, diskriminasi ras, gender, dan sebagainya.
Selama beberapa dekade isu yang cukup banyak diangkat oleh pengarang, baik pengarang perempuan maupun pengaranglaki-laki salah satunya adalah ketidakadilan gender. Ketidakadilan gender merupakan permasalahan yang diwariskan oleh budaya patriarki. Paham patriarki merupakan paham yang memosisikan laki-laki sebagai pihak superior dan perempuan dianggap sebagai pihak inferior. Paham patriarki memosisikan perempuan sebagai pihak yang dirugikan dan membatasi ruang gerak perempuan.

Bentukketidakadilanyangdirasakan perempuan tidak hanya dalam sektor publik, namun juga sektor privat. Dalam sekrot publik, perempuan diberikan batasan dalam mengembangkan eksistensi dirinya, seperti pembatasan pendidikan, pembatasan dalam keterlibatan berpolitik, dan dalam dunia 
kerja perempuan diperlakukan dengan tidak baik serta mendapatkan upah yang lebih rendah daripada laki-laki. Dalam sektor domestik perempuan banyak mengalami kekerasan dan diperlakukan sewenang-wenang oleh suami, perempuan dijadikan sebagai pemenuh kebutuhan laki-laki. Fakih (2012:13) mengungkapkan bahwa ketidakadilan gender termanifestasikan dalam berbagai bentuk ketidakadilan, yakni marginalisasi atau proses pemiskinan ekonomi, subordinasi atau anggapan tidak penting dalam keputusan politik, pembentukan stereotipe atau melalui pelabelan negatif, kekerasan, beban kerja lebih panjang dan lebih banyak, serta sosialisasi ideologi nilai peran gender.

Budaya patriarki secara tidak langsung melahirkan stigma inferioritas bagi perempuan sehingga perempuan dipandang sebagai kaum rendah dan banyak mendapatkan ketidakadilan dalam kehidupan masyarakat. Seiring perkembangan zaman gerakan-gerakan perlawanan terhadap paham patriarki mulai bermunculan. Gerakan-gerakan tersebut dikenal dengan gerakan feminis yang bertujuan untuk menuntut hakhak perempuan dalam kehidupan sosial agar tidak lagi terjadi penindasan dan ketidakadilan pada kaum perempuan.

Gerakan feminis pada umumnya bukan bertujuan untuk mengungguli atau melakukan dominasi pada kaum laki-laki, inti dari gerakan ini adalah penghapusan kekerasan dan diskriminasi pada kaum perempuan. Hal tersebut sesuai dengan pendapat Djajanegara (2000:4) yang menyatakan bahwa tujuan feminis adalah meningkatkan kedudukan dan derajat perempuan agar sama atau sejajar dengan kedudukan dan derajat lakilaki sehingga perempuan memiliki peluang yang sama dengan laki-laki dan tidak lagi terjadi penindasan pada perempuan.

Gender merupakan istilah yang digunakan dalam membedakan perempuan dan laki-laki yang merupakan bentukan dari budaya bukan bawaan. Utaminingsih (2017:2) mengatakan bahwa gender merupakan konstruksi sosial atau atribut yang dikenakan pada manusia yang dibagun oleh kebudayaan manusia. Oleh sebab itu, gender dapat berubah dari suatu wilayah ke wilayah lain, dari suatu zaman ke zaman lain, bahkan dari suatu strata sosial ke strata sosial lain.

Gender yang pada dasarnya merupakan bentukan dari konstruksi sosial yang menyebabkan terjadinya perbedaan peran, fungsi, hak, dan perilaku antara laki-laki dan perempuan. Adanya perbedaan-perbedaan tersebut akhirnya menyebabkan terjadinya persoalan gender yang merugikan perempuan. Hayati (2012:165) menganggap bahwa persoalan gender muncul ketika ketimpanganketimpangan terjadi dalam relasi gender yang melahirkan berbagai ketidakadilan. Ketidakadilan gender selanjutnya menyebabkan perempuan kehilangan hak-haknya dalam berbagai ranahkehidupansehinggamenyebabkan kaum perempuan termarginalkan.

Marginalisasi terhadap perempuan pada akhirnya membuat perempuan menjadi pihak yang dinomorduakan, disubordinasikan, dan dilabeli atau diberi stigma negatif. Hal ini tentu saja membuat perempuan semakin menderita dan terkekang. Adanya perbedaan gender secara tidak langsung 
juga memberikan garis batas antara dikotomi peran laki-laki dan perempuan dalam kehidupan. Perempuan yang memiliki sifat feminin dianggap lebih pantas untuk berkecimpung di sektor domestik, seperti membersihkan rumah, memasak, mengurus anak, dan hal-hal lain yang selaras dengan sifat feminin perempuan. Peran tersebut berbeda dengan laki-laki yang memiliki sifat maskulin, laki-laki sepantasnya bekerja di luar rumah dan mengurusi hal-hal yang membutuhkan kekuatan fisik di ranah publik.

Adanya pembatasan tersebut menyebabkan perempuan tidak dapat hidup mandiri dan menggantungkan penghasilan pada laki-laki sehingga hal ini pulalah yang dapat memicu munculnya kekerasan dalam rumah tangga. Ketidakberdayaan perempuan menyebabkan kaum laki-laki semenamena dalam memperlakukan perempuan. Udasworo (2018:12) menyatakan bahwa sikap perempuan yang ideal adalah perempuan yang mengabaikan karier dan pendidikan, menunjukkan perilaku feminin, lemah, selalu membutuhkan bantuan laki-laki, tidak mandiri, tidak memiliki kekuatan dalam menentukan sikap, dan memuja laki-laki.

Dalam dunia sastra, penggambaran gender dapat ditemukan dari berbagai sudut pandang, misalnya konstruksi gender di lingkungan masyarakat dan ketidakadilan gender yang dialami perempuan. Penggambaran tersebut dilakukan baik oleh pengarang lakilaki maupaun pengarang perempuan. Penggambaran tersebut ada yang sifatnya menolak konstruksi gender dan ketidakadilan gender, namun ada juga yang mendukung konstruksi gender.
Oleh karena itu, dalam dunia sastra gender bukanlah hal yang baru.

Perempuan dalam pandangan patriarki merupakan kaum yang dinomorduakan dan keberadaannya selalu dikesampingkan. Perempuan dianggap sebagai kaum yang keberadaannya hanya digunakan untuk melayani kebutuhan laki-laki. Menurut Nugroho (2019:149) perempuan di berbagai wilayah kehidupan baik sosial, politik, ekonomi, agama, maupun budaya selalu dimarjinalkan di bawah dominasi superioritas kaum laki-laki. Berawal dari buruknya posisi perempuan dalam kehidupan tersebut maka muncullah gerakan feminisme.

Feminisme muncul sebagai sebuah gerakan perempuan yang tidak sekadar hanya membicarakan tentang perempuan dengan segala permasalah yang dihadapinya, tetapi bagaimana perempuan berusaha bangkit untuk melakukan sebuah konstruksi tradisi terhadap segala sesuatu yang mengekang dirinya untuk dapat turut memajukan pemerintahan sebagaimana dilakukan oleh kaum laki-laki. Keinginan kaum perempuan dalam paham ini adalah untuk menyetarakan haknya sebagai seorang manusia yang tidak disubordinasi oleh pihak yang berkuasa agar kehadiran mereka dapat diperhitungkan dan sudah selayaknya mereka dapat turut serta bertindak atau menyuarakan pemikiran mereka di hadapan khalayak tanpa mempermasalahkan jenis kelamin. Hal tersebut senada dengan pendapat Fakih (2012:63) bahwa perjuangan feminisme merupakan perjuangan dalam rangka mentransformasikan sistem dan struktur sosial yang tidak adil menjadi adil bagi laki-laki dan perempuan. 
Keinginan adanya kesataraan dan keadilan gender tidak hanya berhenti dalam kehidupan bermasyarakat saja, namun merambah ke dunia sastra. Thornman (2010:70) mengatakan bahwa kaitan feminisme dalam sastra adalah bahwa karya sastra merupakan salah satu wujud ideologi patriarki. Hal tersebut terbukti dari banyaknya penggambaran perempuan sebagai kelas kedua yang didominasi oleh lakilaki dalam teks-teks sastra. Melalui teks sastra yang dipengaruhi oleh ideologi patriarki, perempuan dan laki-laki ditampilkan dalam keadaan timpang yang memosisikan perempuan sebagai pihak inferior. Edwar, Sarwono, dan Chanafiah (2017:228) mengatakan bahwa tugas bagi feminis sastra digunakan untuk mencari tahu pemicu ketimpangan gender, cara perempuan dinarasikan, dan peran tokoh perempuan di dalam karya sastra.

Kritik sastra feminis mempunyai tujuan yang tidak jauh berbeda dengan gerakan feminisme, bedanya hanya terletak pada medianya. Jika gerakan feminisme menuntut adanya kesataraan gender dan penolakan terhadap ketidakadilan gender dalam kehidupan, kritik sastra feminis berusaha untuk melihat dan mengkaji peran dan kedudukan perempuan dalam karya sastra. Hal tersebut sesuai dengan pendapat Puspita (2019:31) yang menekankan bahwa kritik sastra feminis lahir untuk menyoroti persoalan perempuan yang menuntut persamaan hak dan kesetaraan gender karena adanya ketidakadilan gender yang mengungkung perempuan. Oleh sebab itu, kritik sastra feminis tidak hanya terbatas pada teks-teks sastra yang ditulis dan dibaca oleh perempuan saja, namun juga tentang penggambaran tokoh perempuan di dalam karya sastra.

Kritik sastra feminis sama halnya dengan feminisme yang memiliki beberapa ragam. Namun, dalam penelitian ini kritik sastra feminis yang digunakan adalah kritik sastra feminis ideologis. Kritik sastra feminis ideologis memfokuskan pengkajian pada pelabelan atau citra perempuan yang terdapat di dalam karya sastra. Emzir dan Rohman (2015:160) mengatakan bahwa kritik sastra feminis ideologis membantu terwujudnya tujuan para feminis untuk membongkar segala persoalan yang berkaitan dengan perspektif negatif perempuan, kesalahpahaman tentang perempuan, dan faktor penyebab perempuan sering dinomorduakan.

Bentuk perlawanan terhadap stigma inferioritas perempuan tidak hanya dilakukan melalui kehidupan nyata dengan menggelar aksi dan pemberian edukasi terhadap lingkungan, namun dilakukan pula melalui karya sastra, salah satunya novel. Dalam dunia sastra, kajian karya sastra dengan menggunakan perspektif feminisme melahirkan kritik sastra feminis. Menurut Djajanegara (2000:18), kritik sastra feminis berawal dari kenyataan bahwa baik kanon sastra tradisional maupun pandangan tentang manusia dalam karya sastra pada umumnya mencerminkan ketimpangan.

Novel-novel yang di dalamnya menggambarkan tentang perlawanan stigma inferioritas perempuan sebenarnya telah ada sejak dahulu dan penulisnya pun tidak berbatas pada penulis perempuan saja. Salah satu novel yang di dalamnya menggambarkan 
sosok perempuan teguh pendirian dan memilikikeberaniandalammenentukan jalan hidupnya adalah novel karya Pramoedya Ananta Toer yang berjudul Midah(SiManisBergigiEmas). Novelyang diterbitkan pada tahun 1955 tersebut berusaha memberikan gambaran bahwa perempuan bukanlah sosok yang lemah dan hanya bisa menggantungkan hidup pada kaum laki-laki. Pram berusaha memberikan pandangan baru tentang sosok perempuan, sebagai sosok yang tangguh dan berani dalam mengambil keputusan untuk kebahagiaannya meskipun dalam proses pengambilan keputusan tersebut masih ada keraguankeraguan yang dirasakan di dalam hati.

Novel lain yang di dalamnya lebih tegas dalam menggambarkan perempuan sebagai sosok yang kuat dan mandiri masa kini adalah novel karya Ninik M. Kuntarto yang berjudul Di Balik Kerling Saatirah (DBKS). Novel yang terbit pada tahun 2010 ini menggambarkan tentang sosok perempuan bernama Saatirah yang menerima perlakuan tidak adil dari suaminya serta diperlakukan dengan tidak baik. Namun di sisi lain, sang perempuan bukanlah sosok yang lemah dan pasrah dalam menerima segala ketidakadilan, ia merupakan sosok perempuan yang kuat dan mempunyai kepercayaan diri dalam membuktikan eksistensi dirinya. Melalui sosok Saatirah, Ninik memberikan gambaran tentang sosok perempuan masa kini yang tidak hanya mengabdikan dirinya dalam kehidupan berumah tangga, namun juga memiliki karier yang sukses.

Berdasarkan uraian tersebut maka peneliti tertarik untuk melakukan penelitian dengan judul Melawan Stigma Inferioritas Perempuan: Kajian Novel Midah (Si Manis Bergigi Emas) Karya Pramoedya Ananta Toer dan Novel Di Balik Kerling Saatirah Karya Ninik M. Kuntarto. Penelitian ini bertujuan mendeskripsikan bentuk ketidakadilan gender dan bentuk perlawan perempuan terhadap stigma inferioritas dalam kedua novel berbeda masa tersebut.

\section{METODE}

Penelitian ini merupakan penelitian kajian teks dengan teori kritik sastra feminis. Kritik sastra feminis yang dimaksud dalam penelitian ini yaitu membaca sebagai perempuan (reading as a woman). Sugihastuti dan Suharto (2016:18) mengatakan bahwa membaca sebagai perempuan menuntut kesadaran pembaca mengenai adanya perbedaan penting dalam jenis kelamin pada makna karya sastra. Membaca sebagai perempuan digunakan sebagai media untuk membongkar ideologi kekuasaan laki-laki yang menyebabkan marginalisasi terhadap perempuan.

Jenis penelitian ini adalah penelitian kualitatif, yaitu penelitian yang menggambarkan tingkah laku individu, gejala, keadaan, atau kelompok tertentu. Sesuai dengan permasalahan yang diteliti, penelitian ini berupaya mendeskripsikan bentuk ketidakadilan gender dan bentuk perlawanan perempuan terhadap stigma inferioritas dalam novel Midah karya Pramoedya Ananta Toer dan novel $D B K S$ karya Ninik M. Kuntarto. Data penelitian berupa kata-kata dan bukan dalam bentuk angka-angka. Sumber data penelitian ini, yaitu novel Midah karya Pramoedya Ananta Toer yang diterbitkan pertama kali oleh NV 
Nusantara pada tahun 1995, kemudian kembali diterbitkan oleh Lentera Dipantarayang cetakankelimanya terbit pada tahun 2010 dan novel $D B K S$ karya Ninik M. Kuntarto yang diterbitkan oleh PT Gramedia Widiasarana Indonesia pada tahun 2010. Pada penelitian ini, posisi peneliti dalam sebagai human instrument berfungsi menetapkan fokus penelitian, melakukan pengumpulan data, menilai kualitas data, analisis data, menafsirkan data, dan membuat simpulan atas temuannya.

Data penelitian ini merupakan kutipan-kutipan dialog, monolog, dan narasi yang sesuai dengan tujuan penelitian. Teknik pengumpulan data dilakukan dengan membaca kritis dan membaca berkesinambungan. Analisis data dilakukan dengan cara (1) kodifikasi data, (2) pengelompokan data, (3) interpretasi makna teks, (4) deskripsi bentuk ketidakadilan gender dan bentuk perlawanan gender, serta (5) penyimpulan hasil analsisis.

\section{HASIL DAN PEMBAHASAN Hasil}

Berdasarkan fokus penelitian, hasil penelitian ini mencakup dua hal, yaitu ketidakadilan gender yang didapatkan dua tokoh perempuan dalam dua novel yang dikaji dan bentuk perlawanan yang dilakukan oleh kedua tokoh perempuan tersebut untuk membuktikan eksistensinya. Hasil penelitian diuraikan sebagai berikut.
Pertama, bentukketidakadilangender yang dialami oleh Midah berasal dari orangtuanya yang menjodohkan dirinya dengan pria yang disukai sang ayah tanpa memberikan Midah kesempatan untuk mengutarakan pendapatnya. Selain itu, Midah pun mendapatkan ketidakadilan dalam masalah percintaan, pria yang dicintainya hanya memanfaatkan dirinya sebagai pemuas hawa nafsu, tanpa mau bertanggung jawab menikahinya. Hal berbeda ditemukan pada sosok Saatirah. Meskipun Saatirah sosok perempuan yang hidup di zaman modern dapat memilih jodohnya sendiri, tetapi ia pun mendapatkan ketidakadilan gender yang bersumber dari rumah tangga yang dibinanya dengan sang suami yang bernama Andro. Ketidakadilan gender yang didapatkan oleh Saatirah adalah adanya marginalisasi, subordinasi, pelabelan negatif, dan kekerasan yang diterimanya dalam kehidupan berumah tangga.

Kedua, selain terdapat bentuk ketidakadilan gender, dalam kedua novel tersebut ditemukan pula bentuk perlawanan perempuan terhadap stigma inferioritas. Bentuk perlawanan dalam kedua novel tersebut tergambar melalui sikap dan perilaku Midah dan Saatirah yang keluar dari batas-batas norma yang selama ini diberikan oleh masyarakat dalam kehidupan rumah tangga dan domestik.

Secara lebih jelas hasil dari kedua fokus penelitian tersebut dapat dilihat melalui Tabel 1 berikut. 
Tabel 1. Bentuk Ketidakadilan Gender dan Perlawanan Permpuan dalam Novel Midah dan DBKS

\begin{tabular}{|c|c|c|}
\hline Fokus Penelitian & Novel Midah & Novel $D B K S$ \\
\hline $\begin{array}{l}\text { Bentuk ketidakadilan } \\
\text { gender }\end{array}$ & $\begin{array}{l}\text { Perjodohan tanpa meminta } \\
\text { persetujuan dari Midah } \\
\text { - Budak hawa nafsu pria yang } \\
\text { dicintai oleh Midah }\end{array}$ & $\begin{array}{l}\text { - Marginalisasi Saatirah dalam } \\
\text { kehidupan rumah tangga } \\
\text { - Subordinasi sosok Saatirah } \\
\text { - } \text { Pelabelan negatif } \\
\text { - Kekerasan dalam rumah tangga }\end{array}$ \\
\hline $\begin{array}{l}\text { Bentuk perlawanan } \\
\text { perempuan terhadap } \\
\text { stigma inferioritas }\end{array}$ & $\begin{array}{l}\text { - Melarikan diri dari suami yang } \\
\text { tidak dicintai dan memiliki } \\
\text { banyak istri } \\
\text { - Menentukan jalan hidup yang } \\
\text { diinginkannya sendiri }\end{array}$ & $\begin{array}{l}\text { - Ketidaksetiaan Saatirah } \\
\text { - Kemandirian Saatirah secara } \\
\text { finansial } \\
\text { - Sosok Saatirah yang kuat dan } \\
\text { melakukan segala cara untuk } \\
\text { mewujudkan keinginannya }\end{array}$ \\
\hline
\end{tabular}

\section{Pembahasan}

Berdasarkan hasil penelitian yang berfokus pada dua hal, yaitu bentuk ketidakadilan gender dan bentuk perlawanan perempuan terhadap stigma inferioritas maka pembahasan tentang kedua fokus tersebut diuraikan sebagai berikut.

\section{Bentuk Ketidakadilan Gender}

Ketidakadilan gender telah terjadi sejak masa lampau dan hingga kini masih meninggalkan jejak. Ketidakadilan gender menyebabkan terjadinya kesenjangan dalam kehidupan, kekerasan, ketidaksetaraan hak, dan hal-hal negatif lainnya. Ketidakadilan gender yang merupakan warisan dari budaya patriarki secara garis besar merugikan kaum perempuan yang dipandang sebagai kaum inferior. Bentuk ketidakadilan gender yang menimpa perempuan tidak hanya menimpa perempuan pada masa sebelum teknologi berkembang pesat tetapi juga pada masa teknologi canggih seperti saat ini.

Ketidakadilan gender pada perempuan pada masa tahun 50- an dapat dilihat dari sosok Midah dalam novel Midah. Sebagai seorang perempuan yang hidup pada masa pernikahan muda dan perjodohan dianggap sebagai tradisi, Midah tidak memiliki hak untuk memilih jodoh yang diinginkannya. Ia harus menuruti keinginan orangtuanya dan menikah dengan jodoh yang telah dipilihkan oleh orangtuanya. Midah tidak memiliki wewenang untuk menolak dan menentukan hidupnya sendiri. Ia terkekang budaya masyarakat pada masa itu yang sangat membatasi ruang gerak perempuan.

"Sekarang hadji yang diharapkan itu datang melamar pada bapakmu. Ia punya sawah banyak, kerbau berpuluh-puluh, ibadatnya kuat. Ah, engkau akan mendapat suami yang baik, yang takut pada Tuhan."(M.D.20)

Kutipan tersebut menunjukkan bahwa sosok Midah, sebagai seorang anak perempuan harus pasrah dengan perjodohan yang diatur oleh orangtuanya. Budaya patriarki yang saat itu masih sangat kental menjadikan 
Midah tidak berdaya. Ia tak memiliki kekuasaan untuk menyampaikan isi hatinya meskipun kepada orangtuanya sendiri. Hal tersebut sesuai dengan pendapat Pranowo (2013:58) yang menyatakan bahwa dalam budaya patriarkis, perempuan merupakan makhluk nomor dua dan mereka senantiasa didiskriminasi seturut peranannya di tengah masyarakat. Hal senada disampaikan pula oleh Nurkhalifah (2017:126) yang menyatakan bahwa Kartini dalam surat-suratnya mengatakan pada sang sahabat pena bahwa di Jawa perjodohan dilaksanakan secara sepihak tanpa persetujuan si perempuan, namun atas persetujuan orang tua atau pihak saudara laki-laki si gadis.

Hal mengenai jodoh merupakan hal yang krusial, oleh karena itu seharusnya perempuan tidak dikekang dengan adat perjodohan. Seharusnya, perempuan dapat menentukan jodoh yang diinginkannya sesuai dengan kehendak hatinya karena yang akan menjalani kehidupan berumah tangga adalah si anak perempuan bukan si orangtuanya. Setidak-tidaknya, sebelum menerima pinangan dari pihak laki-laki, orangtua harunya bertanya terlebih dahulu kepada anak perempuannya. Hal itu harusnya dilakukan agar anak perempuan juga memiliki wewenang dalam menerima atau menolak lamaran yang datang untuknya. Rizqi (2014:277) mengatakan bahwa perempuan juga berhak merasakan kebahagiaan yang sesungguhnya dan berhak memiliki kesempatan yang sama dengan seorang laki-laki dalam segala hal selama dia mampu, dan perempuan juga seharusnya memiliki kebebasan mutlak atas dirinya sendiri dalam kehidupan.
Bentuk ketidakadilan gender lainnya yang dirasakan oleh sosok Midah adalah ketika dirinya jatuh cinta kepada seorang pria yang berprofesi sebagai polisi, bernama Ahmad. Pria yang menjadi pelabuhan hatinya itu sayangnya hanya menjadikan Midah sebagai pelampiasan hawa nafsu dan penyalur hasrat tanpa ingin bertanggung jawab pada Midah dan anaknya bahkan saat Midah mengandung anak Ahmad, pria itu menolaknya dan tak mempercayai ucapan Midah.

"Akui ini anakmu. Beri aku surat sah, bahwa ini anakmu. Aku dengan kejadian ini akan bertanggung jawab. Tetapi akui ini anakmu..."

"...Aku tidak punya anak! Tidak!" (M.D.109)

Kutipan tersebut menunjukkan seorangMidahyangtakdapatmelakukan apa-apa ketika pria yang dicintai dan bapak dari anak yang dikandungnya menolak untuk bertanggung jawab. Ia hanya bisa berusaha menjalani kehidupannya tanpa suami. Midah dianggap rendah oleh Ahmad karena tinggal di jalanan. Kodrat perempuan yang bertindak berdasarkan perasaan membuat Midah terjerumus dalam dosa dengan melakukan hubungan di luar nikah meskipun dia terlahir dari keluarga yang taat agama.

Ketika perempuan jatuh cinta, dia akan menyerahkan segalanya pada pria yang dicintainya tanpa memikirkan akibatnya di masa depan. Berbeda dengan pria yang lebih mengedepankan logika daripada perasaan. Ahmad yang masih muda dan senang hidup bebas tentu saja memilih untuk mengingkari perbuatannyadan menolakbertanggung jawab pada darah dagingnya karena 
ia tidak ingin menjadi pria terikat. Ia menginginkan kebebasan, hidup tanpa kekangan dan beban mengurus orang lain.

Melalui sosok Midah, Pram menggambarkan ketidakadilan secara gender yang harus diterima oleh seorang perempuan yang ditakdirkan untuk mengandung dan melahirkan seorang anak. Seorang perempuan saat melakukan hubungan dengan pria tanpa ikatan pernikahan akan mendapatkan konsekuensi lebih besar daripada pria. Sanksi sosial yang diterima oleh perempuan pun lebih kejam karena jika perempuan itu sampai hamil di luar nikah akan banyak dibicarakan oleh orang sekitar dan akan dicemooh. Berbeda dengan pria meski melakukan hubungan dengan banyak perempuan, masyarakat tidak akan mudah untuk mengetahuinya kecuali secara langsung menangkap basah karena pria tidak bisa mengandung dan melahirkan. Menurut Pradana (2012:17) marginalisasi perempuan dapat terlihat dari stereotip negatif terhadap kesetaraan potensi kualitas perempuan dengan laki-laki dan kekerasan terhadap perempuan berdasarkan kuat oleh hierarki laki-laki sebagai subyek dan perempuan sebagai obyek, termasuk ketidaksetaraan gender dalam hal pengalaman seksual sebelum menikah.

Perempuan yang melakukan hubungan badan dengan pria tanpa hubungan pernikahan dianggap masyarakat sebagai perempuan hina, sampah masyarakat, perempuan murahan, dan sebutan-sebutan kejam lainnya. Cemoohan masyarakat akan semakin menjadi saat perempuan tersebutmengandung anakdiluarnikah, yang dicemooh dan dipermalukan bukan hanya si perempuan saja tetapi juga anak yang dikandung dan dilahirkannya.

Masyarakat akan mengatai anak itu dengan sebutan anak haram, anak tak diharapkan, dan sebutan menghina lainnya. Hal ini tentu saja tidaklah adil untuk perempuan karena yang disalahkan hanya pihak perempuan saja, sedangkan pihak si pria jarang sekali ada hinaan dan penyebutan pria murahan, terutama pada masa tahun 50-an. Hal tersebut sesuai pendapat Ardiansyah (2012:85) yang menyatakan bahwa sangat mudah bagi masyarakat untuk melekatkan stereotip negatif pada perempuan, bahkan bagi perempuan itu sendiri, seperti memberikan sebutan perempuan gatel, nakal, murahan serta gampangan, hal yang tidak akan terjadi pada laki-laki.

Penggambaranketidakadilangender pada perempuan masa kini dapat ditemukan melalui penggambaran sosok Saatirah dalam novel $D B K S$. Bentuk ketidakadilan gender pertama yang dapat ditemukan dalam novel tersebut adalah marginalisasi tokoh Saatirah sebagai seorang istri dan ibu dalam rumah tangga. Dalam novel tersebut Saatirah digambarkan sebagai sosok istri yang sempurna dan selalu melayani suaminya dengan sepenuh hati. Selain itu, ia juga seorang ibu yang selalu mengutamakan kebahagiaan anak-anaknya.

Seminggu setelah Mas Andro kembali dari luar kota, seperti biasa, sebelum tidur kuciptakan keindahan dan kuuraikan kemesraan dengan memijat kaki, menarik-narik jemari, mengurut kepala, dan menginjak-injak punggung Mas Andro. Kulaksanakan sambil 
bercerita tentang anak-anak dengan penuh kasih hingga ia tertidur lelap. (DBKS.N.89)

Kutipan tersebut menunjukkan kebaktian seorang istri pada suaminya. Saatirah dengan senang hati dan ikhlas melayani sua3minya. Saatirah dengan penuh cinta memijat kaki suaminya, berusaha untuk membuat sang suami merasa senang, ia juga mengurut kepala suaminya untuk menghilangkan rasa penat setelah melakukan perjalanan jauh. Selain itu, ia juga menceritakan tentang perkembangan anak-anak mereka dengan penuh kasih sayang.

Melalui kutipan tersebut dapat dilihat bahwa perempuan zaman ini masih terkungkung pada konsep lama untuk selalu berbakti dan melayani suami. Istri dituntut untuk mengurusi segala kebutuhan suami. Selain harus melayani suami, istri juga diberikan tanggung jawab untuk mendidik dan merawan anak. Seorang perempuan yangtelahmenjadiistridiwajibkanuntuk selalu membahagiakan sang suami dan membuat sang suami selalu merasa nyaman. Berbeda dengan laki-laki sebagai sosok suami yang tidak dituntut untuk melayani dan menyenangkan hati istrinya. Hal tersebut karena adanya perbedaan tingkat antara perempuan dan laki-laki. Rahmawaty (2015:3) memaparkan bahwa masyarakat yang masih melakukan pengelompokan pemahaman tentang subyek-obyek, dominan-tidak dominan, superiorimperior serta pembagian peran-peran yang tidak seimbang antara anggota keluarga laki-laki dan perempuan membuat laki-laki lebih mendapatkan hak-hak istimewa, sedangkan perempuan sebagai kaum kelas kedua memiliki ruang gerak yang terbatas.

Penggambaran perempuan yang demikian dalam novel $D B K S$ secara tidak langsung menjadi bukti bahwa pengarang masih terpengaruh terhadap paham patriarki yang memosisikan perempuan sebagai kaum yang dilahirkan untuk mengurusi urusanurusan rumah, melayani suami, dan mengasuh anak. Hal tersebut sesuai dengan pendapat Ritzer dan Goodman (2004:433) yang menyatakan bahwa konsep patriarki masyarakat Jawa memandang perempuan sebagai sosok ibu dan istri yang tugas dan tanggung jawabnya cukup berat di keluarga Jawa. Penggambaran sosok perempuan dalam sebuah keluarga yang demikian menjadikan perempuan seperti seorang "pelayan".

Bentuk ketidakadilan gender kedua yang ada di dalam novel $D B K S$ adalah subordinasi. Saatirah meskipun telah berusaha untuk menjadi istri yang baik dan ibu yang sempurna untuk anak-anaknya, namun kedudukan tidak dianggap penting, pendapatnya dianggap sebagai hal yang tidak perlu didengarkan. Andro sebagai seorang suami beranggapan bahwa dirinyalah yang berhak mengambil setiap keputusan dalam rumah tangga.

Mas Andro adalah orang yang keras, cenderung kasar. Saklek. Menurut dia hitam, ya hitam. Menurut dia putih, ya harus putih. Aku tidak bisa mengeluarkan pendapatku bila tidak diminta. Dan celakanya, ia tidak pernah meminta pendapatku. Baginya aku adalah orang yang dipilih, bukanyangmemilih. Baginya aku adalah orang yang diputuskan, bukan orang yang memutuskan. 
Bila aku menjawab, baginya aku membantah. (DBKS.D.99)

Kutipan tersebut menunjukkan bahwa suami merupakan tokoh utama dalam rumah tangga yang bertanggung jawab dalam memimpin dan mengambil keputusan. Suami adalah pengambil keputusan dan istri harus menerima keputusan yang telah diambil oleh suami. Pada umumnya, dalam berumah tangga suamilah yang dijadikan panutan, dianggap sebagai pemimpin, pengarah, dan pengambil keputusan utama. Istri harus patuh dan mengikuti keputusan suami. Perempuan masih belum bisa keluar dari budaya patriarki sehingga tidak mampu bersuara dan melawan suami yang menyebabkan ruang gerak perempuan dalam rumah tangga sangatlah terbatas sehingga terjadilah pembungkaman pada suara perempuan (Nasution, 2016:140).

Seorang istri meski telah berusaha melakukan yang terbaik dalam rumah tangganya tetap saja berperan sebagai sosok yang tidak terlalu mendapatkan perhatian dan keberadaannya tidak dianggap penting. Herawati (2013:50) menyatakan bahwa perempuan seringkali hanya dianggap sebagai pelengkap status dalam perkawinan dan selalu berada di bawah dominasi lakilaki, seperti mengurus rumah tangga, melayani suami, mengurus anak, dan siap ditinggalkan suami. Istri tidak diberikan hak untuk menyuarakan pendapatnya dan mengutarakan keinginannya.

Selain itu, ketidakberdayaan perempuan dalam novel $D B K S$ juga dapat dilihat dari kepasrahan Saatirah dalam menerima perselingkuhan dan perlakuan buruk yang dilakukan oleh suaminya. Saatirah harus mampu untuk menahan segala derita yang dialaminya dan menyimpannya sendiri, sang suami tidak peduli dan tidak mengetahui hal itu. Ia berusaha untuk tidak menangis dan menahan isakannya saat sang suami bertanya tentang pertemuannya dengan si perempuan selingkuhan. Seorang istri hanya dapat menyimpan dukanya sendiri tanpa dapat membagi lukanya dengan sang suami, sebagaimana dikatakan bahwa perempuan dalam rumah tangga digambarkan sebagai seorang pelayan yang selalu mengalah, ketahanan perempuan untuk menderita dianggap sebagai bagian dari kehidupan perempuan (Nasution, 2016:140).

Bentuk ketidakadilan gender yang ketiga dalam novel $D B K S$ adalah pelabelan negatif. Tyson (dalam Hayati 2012:171) mengatakan bahwa secara tradisional, perempuan dan laki-laki sudah dikonstruksi untuk memerankan peran masing-masing yang kemudian disepakati secara sosial bahwa kesemuanya itu sudah menjadi suatu keharusan. Misalnya, laki-laki yang memiliki sifat maskulin berperan sebagai kepala rumah tangga dan tulang punggu keluarga dengan bekerja di luar rumah sedangkan perempuan yang memiliki sifat feminim berperan sebagai ibu rumah tangga dan pekerjaannya berpusat pada urusan rumah.

Namun, sayangnya dengan adanya garis pembatas antara peran laki-laki dan perempuan tersebut menyebabkan perempuan diposisikan sebagai pihak nomor dua yang dipandang rendah dan banyak mendapatkan perlakuan diskriminatif dari masyarakat. Adanya perbedaan peran tersebut menyebabkan terciptanya pelabelan negatif pada perempuan. Adapun pelabelan negatif 
yang ditonjolkan dalam novel $D B K S$, yaitu perempuan harus patuh dan setia, perempuan adalah pelayan bagi suami, dan perempuan selalu mengutamakan kepentingan keluarga. Nasri (2016:234) menyatakan bahwa ketika seorang istri diperlakukan secara tidak adil oleh suaminya, dia tidak berani melakukan perlawanan karena pasti tidak akan berterima dalam pandangan masyarakat pada umumnya dan akan dianggap istri yang durhaka kepada suami.

Kewajiban seorang perempuan untuk setia dan patuh kepada suaminya merupakan pelabelan yang telah mendarah daging pada diri perempuan. Dalam rumah tangga apabila seorang suami berselingkuh dianggap sebagai suatu hal yang biasa dan diartikan sebagai sifat kodrati yang dimiliki oleh laki-laki, namun apabila perempuan yang melakukannya akan diaggap sebagai "perempuan murahan" dan berbagai hujatan akan mendatangi perempuan tersebut. Hearty (2011:52) berpendapat bahwa jika dalam rumah tangga seorang suami melakukan perselingkuhan, istri dianggap sebagai pihak yang bersalah karena tidak mampu untuk membahagiakan, merawat, dan melayani sang suami.

Menjelang berangkat kerja, tetap ku siapkan segala keperluan suami. Mulai kaos kaki, celana dalam, kaos dalam, parfum, sabuk, celana panjang, sampai kemeja putih, seragamnya ku letakkan di atas kasur di depan pintu kamar mandi. (DBKS.N.91)

Kutipan tersebut menunjukkan bentuk pelayanan dan pengabdian seorang istri kepada suaminya. Dalam kehidupan rumah tangga perempuan dianggap sebagai "pelayan” yang selalu melayani, menyiapkan, dan mengurusi segala hal yang dibutuhkan oleh suami. Sebagai perempuan Jawa, Satirah merupakan wujud dari konsep patriarki masyarakat Jawa yang memandang perempuan sebagai sosok ibu dan istri yang tugas dan tanggung jawabnya cukup berat di keluarga Jawa (Periksa Nasution, 2016:140). Penggambaran sosok perempuan dalam sebuah keluarga yang demikian menjadikan perempuan seperti seorang "pelayan".

Posisi perempuan yang rendah dan seakan-akan tidak berharga menyebabkan perempuan tidak memiliki kekuatan dalam melawan dominasi laki-laki. Hal tersebut menyebabkan perempuan tidak dapat mengembangkan diri dan selalu menjadi pihak inferior. Pelabelan lain yang melekat pada perempuan adalah kelembutan hatinya yang menyebabkan perempuan selalu menempatkan keluarga di posisi pertama dengan mengesampingkan dirinya sendiri. Terutama saat perempuan tersebut telah menjadi ibu, segala hal akan diupayakan demi kesejahteraan anakanaknya.

Seorang ibu rela menahan berbagai rasa sakit asalkan anaknya tetap merasakan kebahagiaan. Seorang ibu tidak ingin anak-anaknya menderita karena keegoisan dirinya dan sang suami. Hal tersebut membuktikan bahwa perempuan selalu mimikirkan kepentingan dan kebahagiaan keluarganya dan mengesampingkan kebahagiaan dirinya. Mulawarman (2014:97) memaparkan bahwa perempuan sebagai ibu memberikan citra yang tidak terlepas dari urusan domestik (rumah tangga), termasuk 
memberi perhatian dan kasih sayang kepada anak-anaknya diiringi dengan perasaan yang penuh dedikasi dan pengorbanan sebesar-besarnya.

Perempuan sejak kecil diberi batasan-batasan dalam bergerak dan berekspresi, misalnya mereka dilarang banyak bermain di luar rumah sehingga kegiatan yang mereka lakukan berpusat di dalam rumah dan mengarah pada kegiatan-kegiatan domestik, seperti membantu ibu di dapur (Nuroho dan Musman, 2018:68). Hal tersbut menyebabkan perempuan tidak dapat menemukan identitas sejatinya karena telah dibatasi dengan kewajiban yang ditetapkan oleh adat turun-temurun. Oleh karena itu, secara tidak sadar mereka telah memahami tugas perempuan sebagai istri dan ibu sejak usia anak-anak. Peran-peran tersebut membuat konstruksi pemikiran seorang perempuan berpusat pada keluarga dan mengesampingkan kepentingan pribadinya. Kuswidarti (2016:10) mengatakan bahwa kepala lembaga patriarki adalah keluarga yang menanamkan nilai-nilai patriakal kepada anak-anak melalui seorang ibu atau nenek. Penanaman ideologi ini sangat memengaruhi sikap anak-anak yang terbawa hingga dewasa.

Bentuk ketidakadilan gender keempat dalam novel $D B K S$ adalah kekerasan. Perempuan yang erat kaitannya dengan sikap lemah dan tidak memiliki kekuatan dalam melawan lakilaki menyebabkan laki-laki bertindak sesuka hati.

Setelah Susan pulang dengan kemarahan yang tak beralasan, malam itu Mas Andro marah besar. Kata-kata kasar ku terima. Pukulan demi pukulan menghantam tubuhku. Tendangan demi tendangan melayang ke tubuhku. Juga siraman air mengguyur tubuhku yang terluka. Perih. Letih. Legam. Memar. (DBKS.N.163)

Kutipan tersebut menunjukkan perlakuan seorang suami yang semenamena pada istrinya. Ia tidak hanya menyakiti sang istri secara verbal, tetapi juga secara fisik. Saat sedang emosi, seorang suami melampiaskan amarahnya dengan cara menendang tubuh istrinya, memukul tubuh istrinya secara bertubi-tubi, dan mengguyur istrinya dengan air.

Kekerasan yang didapatkan oleh Saatirah tersebut merupakan akibat dari dirinya yang meminta Sintia (perempuan selingkuhan sang suami) untuk menjauhi keluarganya. Sayangnya Sintia mengadukan permintaan Saatirah tersebut ke Andro yang membuat Andro marah dan merasa harga dirinya terinjak-injak karena perbuatan Saatirah tersebut. Andro yang merasa marah dan merasa Saatirah tidak mempunyai hak untuk ikut campur dengan kisah asmaranya akhirnya melampiaskan kekesalan dengan menyiksa Saatirah dengan melakukan tindak kekerasan pada sang istri.

Saat menerima perlakuan yang tidak adil dari sang suami, seorang istri tidak memiliki kekuatan untuk melawan bahkan tidak diberikan kesempatan oleh sang suami untuk membela diri. Seorang istri hanya bisa pasrah dalam menerima perlakuan tidak baik dari suaminya. Situasi tersebut sebagaimana digambarkan oleh Nasution (2016:140) bahwa perempuan masih belum bisa keluar dari budaya patriarki sehingga 
tidak mampu bersuara dan melawan suami. Perempuan yang tidak memiliki keberanian dan kekuatan dalam membela diri menyebabkan laki-laki bertindak sewenang-wenang dan sesuka hati sehingga memicu adanya tindak kekerasan pada perempuan.

Ketidaksetaraan gender dalam hal ini sungguh jelas terlihat dari sikap seorang suami yang mampu berbuat apa pun yang dikehendaki kepada sang istri. Ketimpangan kedudukan dan kekuatan antara laki-laki dan perempuan sangatlah merugikan kaum perempuan. Dalam hal ini seharusnya perempuan dapat melakukan perlawanan dan pembelaan diri. Perempuan harus berani mengambil tindakan dan menyadarkan laki-laki bahwa antara laki-laki dan perempuan itu sama, seharusnya tidak ada kekerasan, perempuan adalah makhluk bernyawa yang perlu dihargai dan dihormati layaknya laki-laki (Mahanani, 2019:116).

\section{Bentuk Perlawanan Perempuan terhadap Stigma Inferioritas}

Seiring dengan perkembangan zaman dan semakin banyaknya organisasi perempuan yang terbentuk membuat perempuan mulai mengembangkan diri. Keberadaan perempuan mulai diperhitungkan dan perempuan mulai mendapatkan kesempatan untuk terlibat dalam sektor-sektor publik. Hal tersebut membuat intimidasi, marginalisasi, dan subordinasi pada perempuan mulai berkurang. Secara tidaklangsung stigma inferioritas pada perempuan pun mulai berubah.

Eksistensi perempuan yang mulai diakui di ruang publik tidak hanya terjadi di dunia nyata, namun juga di dunia sastra. Hal tersebut terbukti dari mulai banyaknya pengarang perempuan dan laki-laki dalam bidang sastra yang mulai menghidupkan tokoh perempuan sebagai sosok yang kuat dan dinamis. Tidak hanya itu saja, selama bertahun-tahun tokoh perempuan dicitrakan sebagai pihak yang lemah dan tidak memiliki kekuatan untuk melawaan dominasi laki-laki pun mulai digambarkan berbeda. Dalam novel Midah dan $D B K S$ selain dapat ditemukan bentuk-bentuk ketidakadilan gender, juga dapat ditemukan usaha pengarang dalam mengeluarkan stigma inferioritas pada diri perempuan.

Melalui novel Midah, Pram berusaha menanamkan ideologi-ideologi kemandirian dan keberanian, meskipun penggambaran tersebut masih kabur dan dibayang-bayangi oleh ketakutan dan keraguan. Perlawanan perempuan terhadap stigma inferioritas yang lebih jelas dan tegas dapat ditemukan dalam novel $D B K S$, yang digambarkan melalui sosok perempuan masa kini bernama Saatirah. Ia membuktikan bahwa perempuan dapat bertindak lebih berani dan mengeluarkan dirinya dari pelabelan negatif atau stigma inferioritas yang selama ini melekat dalam diri perempuan.

Bentuk perlawanan perempuan terhadap stigma inferioritas dalam novel Midah dan $D B K S$ dilakukan oleh tokoh Midah dan Saatirah melalui citra diri dan aksi yang dilakukannya. Melalui sosok Midah, pengarang secara perlahan menunjukkan bahwa perempuan pun dapat menentukan jalan hidup sesuai yang diinginkannya. Meskipun dalam prosesnya diwarnai dengan ketidakpercayaan diri, keraguan, dan ketakutan. Sosok Midah 
meruntuhkan pelabelan perempuan yang selama ini dicitrakan sebagai sosok pengabdi suami dan hidup dalam bayang-bayang kekuasaan laki-laki.

Midah dalam ketakutan dan keraguan tetap bertekad memberanikan diri dan menguatkan hati untuk mencari kebahagiannya sendiri. Kesungguhan tentang harapan untuk mendapatkan kebahagian dan kebebasan itu dibuktikan Midah dengan aksinya kabur dari rumah sang suami meskipun dalam keadaan sedang mengandung tiga bulan. Berbekal uang seadanya, ia berusaha untuk memulai kehidupan baru meskipun tidak tahu dengan pasti apa yang harus dilakukannya untuk bertahan hidup.

... ia merasa sebagai sebatang tunggul terpancang di tengahtengah padang. Apalagi setelah diketahuinya bahwa Hadji Terbus bukan bujang dan bukan muda. Bininya tersebar banyak di seluruh Cibatok. Ini diketahuinya waktu ia mengandung tiga bulan. Waktu ia tak sanggup lagi menanggung segalanya, dengan diam-diam ia kembali ke Jakarta. (M.N.21).

Kutipan tersebut menunjukkan keberanian Midah, seorang perempuan korban perjodohan di masa tahun 50-an yang berusaha mengejar kebahagiaanya di tempat lain. aksi yang dilakukan oleh Midah tentu saja merupakan sebuah dobrakan dalam penyitraan perempuan yang selama ini selalu dicitrakan sebagai sosok yang mengabdikan diri pada suami dan kodrat perempuan adalah memasak, menghias diri, serta melayani suami.

Firmansyah (2019:45) menyatakan bahwa pelabelan 3M (memasak, menghias diri, melayani lelaki) sangat merugikan perempuan karena dapat mempersempit ruang perempuan dan menyulitkan perempuan untuk lepas dari citra negatif tersebut. Midah yang saat itu hidup dengan lingkungan adat yang masih sangat kental berhasil membawa dirinya untuk hidup tanpa suami dan membuktikan pada orang lain bahwa perempuan pun bisa hidup mandiri tanpa sosok laki-laki di sampingnya. Meskipun tindakan yang dilakukan Midah itu sangatlah bertentangan dengan norma masyarakat yang saat itu masih memegang teguh prinsip patriarki. Umniyyah (2020:127) menyatakan bahwa sistem patriarki sangat menjunjung tinggi posisi lakilaki, terutama jika telah berstatus suami, seorang istri diwajibkan menerima segala bentuk perlakukan suaminya sekalipun perlakuan tersebut sangat merugikan.

Bentuk perlawanan terhadap stigma inferioritas lain yang dilakukan oleh Midah tergambar melalui aksinya dalam memutuskan untuk memilih jalan hidup sesuai dengan keinginan hatinya tanpa bantuan dan campur tangan orang lain.

Perempuan muda itu lambat-lambat dengan gerak bimbang mulai menjauh meninggalkan ibu dan anaknya sendiri...iaberjalanlambatlambat, seakan ada terdengar suara memanggil-mangilnya...ia tak menengok lagi dan terus berjalan. (M.N.128-129).

Melalui kutipan tersebut pengarang menunjukkan keteguhan hati Midah dalam memutuskan untuk hidup bebas di luar tanpa ingin membebani kedua orangtuanya. Meskipun sempat 
mendapatkan larangan dari sang ibu, namun Midah tetap pada pendiriannya untuk hidup sesuai kehendaknya dan tanpa harus menjadi beban untuk orang lain. Ia dengan keyakinan yang penuh pada dirinya pergi menuju tempat yang dipilihnya sendiri.

Sikap yang diambil oleh Midah tersebut tentu saja bertolak belakang dengan citra perempuan yang lemah dan selalu menuruti kehendak orangtua. Pada masa itu bahkan perempuan cenderung digambarkan sebagai sosok penakut yang tidak memiliki hak dalam menyuarakan pendapatnya. Saputra (2011:19) memaparkan bahwa dalam ideologi patriarki kaum perempuan telah teralienasi sejak mereka terlahir ke dunia dalam ruang masyarakat, diri perempuan adalah milik orangtua, khususnya ayah bukan atas milik sendiri.

Melalui tindakan Midah yang berani mengambil keputusan untuk masa depannya dan menetapkan masa depannya berdasarkan pikirannya sendiri, pengarang berusaha memberikan gambaran kepada masyarakat bahwa seorang perempuan sebenarnya memiliki hak yang sama besar dengan laki-laki dalam menentukan masa depan dan perannya di masyarakat. Perempuan memiliki hak untuk merasakan kebahagian dengan caranya sendiri asalkan tidak membawa kerugian. Perempuan dan laki-laki telah diberi potensi yang sama untuk dapat berkiprah dan beramal secara sinergis dalam asas kemitraan, kerja sama, saling tolong menolong, saling mendukung, saling memberi penguatan dalam suatu kehidupan di masyarakat (Fabriar, 2013:34).
Bentuk perlawanan perempuan terhadap stigma inferioritas selanjutnya dapat terlihat melalui sosok Saatirah, perempuan yang awalnya dicitrakan sebagai sosok yang setia, lemah, bergantung pada suami, dan penurut dibongkar sehingga membentuk citra baru. Saatirah merupakan sosok yang tidak setia pada suaminya, kuat, pemberani, dan tidak mudah menyerah. Ketidaksetiaan Saatirah kepada suaminya dibuktikan dengan aksinya melakukan perselingkuhan dengan seorang wartawan di belakang sang suami jauh sebelum Andro berselingkuh dengan Sintia.

Ah...ah...ah...tiba-tiba kurasakan kehangatan sebuah kuluman di bibirku. Kuluman cinta yang mendalam. $\mathrm{Ku}$ dengar ada desah kenikmatandironggaudara.Kubuka mataku perlahan. Kulihat sepasang mata hampir terbenam bagaikan mentari setengah terendam laut. Sayu. Tak sadarkan diri, ku biarkan ia mengecup bibirku terus dan terus di kala pasrah. $\mathrm{Ku}$ biarkan diriku terbuai di pelukan kehangatan matahari cintanya. (DBKS.N.64)

Kutipan tersebut menunjukkan pengkhianatan seorang istri pada suaminya. Seorang istri melakukan hubungan terlarang dengan pria lain, ia berciuman dengan pria lain tanpa memikirkan sang suami, ia membiarkan dirinya terbuai kenikmatan yang diciptakan pria tersebut. Melalui kutipan tersebut dapat dilihat bahwa Saatirah membiarkan dirinya terbuai dengan kenikmatan yang diciptakan pria lain. Hal ini membuktikan bahwa perselingkuhan tidak hanya dapat dilakukan oleh laki-laki, namun juga 
dapat dilakukan oleh perempuan. Menurut Kurniasari (2009:27) perilaku perselingkuhan merupakan suatu perilaku yang dalam suatu tatanan norma-norma sosial tidak selayaknya dilakukan, namun seringkali dilakukan oleh kaum laki-laki dan dianggap sebagai perilaku yang wajar bagi lakilaki tetapi tidak wajar dilakukan oleh perempuan.

Melalui tokoh Saatirah, perempuan yang selama ini dicitrakan sebagai sosok yang setia berubah menjadi sebaliknya. Perbuatan Saatirah tersebut membuktikan bahwa perempuan bukan lagi sosok yang lemah dan selalu menerima perlakuan tidak adil. Saatirah menunjukkan bahwa perempuan pun dapat melakukan perbuatan-perbuatan yang selama bertahun-tahun lalu hanya dapat dilakukan oleh laki-laki.

Perempuan yang selama ini dicitrakan sebagai sosok yang menggantungkan kehidupannya kepada laki-laki pun didobrak oleh Saatirah. Melalui tokoh Saatirah dapat ditemukan sosok perempuan mandiri yang mampu hidup tanpa uang suaminya.

$\mathrm{Aku}$ berusaha bangkit mengais kekuatan talentaku sebagai model. $\mathrm{Aku}$ pun bisa menjadi model kembali. Kali ini sebagai model iklan di berbagai media massa, aku bisa menjadi narasumber di beberapa seminar, dan dengan cepat aku berhasil menempati posisi direktur untuk sebuah bagian di kampus tempatku mengajar. Terakhir, secara mengejutkan aku dilamar sebagai bakal calon wakil bupati Majalengka. (DBKS.N.135)

Kutipan tersebut menunjukkan usaha Saatirah untuk menjadi perempuan mandiri dan melakukan berbagai hal demi menyetabilkan perekonomian keluarganya. Pada umumnya, seorang istri bekerja di rumah dan mengurusi hal-hal yang berhubungan dengan urusan rumah tangga, namun kutipan tersebut menunjukkan hal yang sebaliknya. Seorang istri berusaha mengeluarkan semua talentanya dengan menjadi model dan menjadi narasumber di beberapa seminar untuk menopang kebutuhan hidupnya dan keluarganya.

Hal tersebut membuktikan bahwa tanpa laki-laki, perempuan pun dapat mencukupi kehidupannya sendiri. perempuan bukan lagi sosok yanglemah dan termarginalkan karena dalam dunia kerja perempuan mulai diperhitungkan dan mendapatkan tempat yang sama dengan laki-laki. Menurut Sukmawati, dkk (2017:186) pandang patrarki pada umumnya perempuan yang dianggap hanya sebagai makhluk lemah lembut lebih pantas hanya mengerjakan pekerjaan-pekerjaan di sektir domestik daripada bekerja di sektor publik. Namun, pandangan tersebut saat dapat dipatahkan, di sektor-sektor swasta dan pemerintahan sudah banyak diduduki oleh perempuan.

Oleh karena itu, saat ini banyak perempuan bersuami yang juga bekerja atau menjadi wanita karier. Hal ini membuktikan bahwa kini perempuan mulai dapat menunjukkan eksistensinya dan mulai mendapatkan keadilan hak-hak yang sama dengan laki-laki. Ismiyati (2011:156) menyatakan bahwa gejala keterlibatan perempuan di luar rumah, dalam sektor publik menandakan bahwa perempuan telah berusaha merekonstruksi sejarah hidupnya dengan membangun identitas 
bagi dirinya, tidak hanya sebagai ibu atau istri, tetapi juga sebagai pekerja dan perempuan karier.

Mulai diakui dan dipertimbangkannya perempuan bekerja di ruang publik tentu saja menjadi angin segar bagi para pejuang feminisme karena hal ini membuktikan bahwa perjuangan mereka dalam menuntut hak-hak perempuan mulai mendapatkan respon yang baik. Bahwa perjuangan feminisme selama ini berfokus pada kesempatan yang sama dan hak yang sama bagi setiap individu, baik laki-laki maupun perempuan, status-status dan peran-peran sosial harus didistribusikan secara merata pada laki-laki dan perempuan, semua orang harus diberkan kesempatan dan hak yang sama dalam mengenayam pendidikan, dunia kerja, dan ranah politik (Magdalene, 2018:67).

Citra lain yang berhasil dipatahkan oleh Saatirah adalah citra perempuan sebagai sosok yang lemah. Melalui sosok Saatirah perempuan berhasil menyitrakan dirinya sebagai sosok yang kuat dan tidak mudah menyerah. Hal tersebut terbukti dari kegigihan Saatirah untuk membuat suaminya kembali mencintai dirinya. Saatirah melakukan berbagai macam cara agar sang suami dapat kembali ke pelukannya, ia melakukan berbagai perawatan bahkan melakukan perbuatan syirik untuk mencapai tujuannya.

Aku ingin menjadi perempuan yang paling menarik di mata Mas Andro. Juga di mata perempuan itu. Sejak saat itu, aku rajin mengunjungi Anyelir, bertemu dengan Mamak. Suatu ritual unik yang kuikuti adalah meraga sukma. (DBKS.N.137)
Kutipan tersebut menunjukkan perbuatan syirik yang dilakukan oleh Saatirah. Perempuan tersebut melakukan perbuatan yang dilarang agama dan percaya pada kekuasaan selain kuasa Allah dengan percaya pada ritual-ritual tertentu, seperti ritual meraga sukma demi mencapai keinginannya. Perbuatan Saatirah tersebut memunculkan citra baru perempuan sebagai sosok yang berani, kuat, dan tidak mudah menyerah.

Saatirah menunjukkan bahwa perempuan juga memiliki kemampuan untuk mewujudkan keinginannya dan bukan hanya laki-laki saja yang dapat melakukannya. Pencapaian Saatirah tersebut tentunya juga tidak lepas dari perjuangan perempuan selama ini dalam memperoleh keadilan dan adanya perkembangan zaman yang berpengaruh pada terbukanya pola pikir masyarakat. Sejarah banyak menggambarkan tentang kondisi ketertindasan perempuan dan terampasnya hak politik perempuan menimbulkan kesadaran dan terbukanya pola pikir perempuan untuk keluar dari diskriminasi yang selama ini membayanginya (Murniati, 2004:124).

\section{SIMPULAN}

Hasil penelitian ini menunjukkan bahwa bentuk ketidakadilan gender telah disajikan baik dalam novel Midah karya Pramoedya Ananta Toer, maupun dalam novel $D B K S$ karya Ninik $\mathrm{M}$. Kuntarto sekalipun persoalannya berbeda. Pada novel Midah Pram telah menyingung masalah ketidakadilan gender dalam hubungannya dengan penghargaan terhadap perempuan dalam menentukan jodohnya dan perlakuan yang tidak adil oleh 
seorang laki-laki terhadap wanita yang mencintainya. Pram telah mencoba berpihak pada perempuan meskipun pada masa itu budaya patriarki masih sangat kental hidup di lingkungan masyarakat Indonesia.

Bentuk ketidakadilan gender yang lebih kompleks dan diwarnai cara pandang modern ditemukan dalam novel $D B K S$ karya Ninik $\mathrm{M}$. Kuntarto. Pada Novel DBKS, Ninik menggambarkan perjuangan seorang wanita yang berperan ganda sebagai ibu rumah tangga dan wanita karier. Meskipun tokoh Saatirah hidup pada zaman modern dengan lingkungan yang lebih menghargai sosok perempuan, namun ternyata ketidakadilan gender masih dapat dirasakannya dalam sektor domestik. Ia mendapatrkan perlakuan tidakadilan oleh suaminya dalam bentuk: marginalisasi perempuan, subordinasi, pelabelan negatif, dan kekerasan dalam rumah tangga.

Hasil penelitian ini juga menunjukkan bahwa kedua novel: novel Midah karya Pramoedya Ananta Toer, maupun dalam novel $D B K S$ karya Ninik M. Kuntarto telah mengangkat bentukperlawanan perempuan terhadap stigma inferioritas dengan tingkat keberanian yang berbeda. Pada novel Midah, Pram telah mewujudkan sikap berani tokoh Midah dengan mengambil keputusan untuk melarikan diri dari suami yang tidak dicintai dan memiliki banyak istri untuk menentukan jalan hidup yang diinginkannya. Sebaliknya, dalam novel DKBS, Ninik masih menyisakan kegamangan dalam tokoh Saatirah saat melakukan perlawanan. Kegamangan tersebut dibungkus dalam perilaku melawan dengan membalas perselingkuhan suami, menunjukkan kemandirian finansial, dan teguh dalam mewujudkan keinginannya. Ia memang memberikan bukti bahwa perempuan juga dapat melakukan tindakan-tindakan yang pada zaman dulu hanya bisa dilakukan oleh pria, namun ia tidak seberani Midah dalam mengambil keputusan.

Tampaknya perbedaan jenis kelamin pengarang turut menentukan perbedaan sikap dalam melawan stigma inferioritas perempuan. Pram sebagai pengarang laki-laki bersikap logis dan lugas dan itu tercermin dalam sikap melawan tokoh Midah, sementara Ninik sebagai pengarang perempuan lebih banyak menimbang-nimbang dalam mengambil keputusan, yakni dengan tetap mempertahankan rumah tangganya. Apa pun bentuknya, kedua pengarang telah mencoba berpihak pada perempuan dalam karyanya dengan tetap mencerminkan latar belakang masing-masing.

\section{DAFTAR PUSTAKA}

Ardiansyah, Arief Sofyan. (2012). Konstruksi Seksualitas Perempuan di Majalah Men's Health. Jurnal Komunikator, 4(2), 80-92. https:// journal.umy.ac.id/index.php/jkm/ article/view/193

Djajanegara, Soenarjati. (2000). Kritik Sastra Feminis Sebuah Pengantar. Jakarta: PT Gramedia Putaka Utama.

Edwar, Sarwono, dan Chanafiah. (2017). Perempuan dalam Cerita Calon Arang Karya Pramoedya Ananta Toer Perspektif Feminis Sastra. Jurnal Ilmiah Korpus, 1(2), 224-232.https://doi.org/10.33369/ jik.v1i2.4137 
Emzir dan Saifur Rohman. (2015). Teori dan Pengajaran Sastra. Jakarta: PT Raja Grafindo Persada.

Endraswara,Suwardi.(2008).Metodologi Penelitian Sastra: Epistemologi, Model, Teori dan Aplikasi. Yogyakarta: Pustaka Widyatama.

Fabriar, Silvia Riskha. (2013). Potret Perempuan dalam Film Perempuan Berkalung Sorban. Jurnal Sawwa, 9(1), 27-44. journal.walisongo. ac.id/index.php/sawwa/article/ download/664/602

Fakih, Mansour. (2012). Analisis Gender dan Transformasi Sosial. Yogyakarta: Pustaka Pelajar.

Firmansyah, Ridho Covinda Wahyu. (2019). Bentuk-Bentuk Pelabelan Negatif terhadap Perempuan dalam Novel Gadis-Gadis Amangkurat Cinta yang Menikam Karya RH Widada. Prosiding SENASBASA, 3(1), 38-48. http://researchreport.umm.ac.id/index.php/ SENASBASA/article/view/2586

Handayani dan Ardhian Novianto. (2004). Kuasa Wanita Jawa. Yogyakarta: PT IKiS.

Hayati, Yenni. (2012). Representasi Ketidakadilan Gender dalam Cerita dari Blora Karya Pramoedya Ananta Toer: Kajian Feminisme. Jurnal Atavisme, 15(2), 163-176. https:// doi.org/10.24257/atavisme. v15i2.57.163-176

Hearty, Free. (2011). Keadilan Jender: Perspektif Feminis Muslim dalam Sastra Timur Tengah. Jakarta: Yayasan pustaka Obor Indonesia.

Herawati, Yudianti. (2013). Citra Perempuan dalam Novel Upacara, Api Awan Asap, dan Bunga Karya Korrie Layun Rampan. Atavisme,
16(1), 43-56. https://core.ac.uk/ reader $/ 194051640$

Ismiyati, Siti Hajar. (2011). Feminisme dalam Kumpulan Cerpen Harga Perempuan Karya Sirikit Syah. Widyaparwa: Jurnal Ilmiah Kebahasaan dan Kesastraan, 39(2), 155-166.https://doi.org/10.26499/ wdprw.v39i2.37

Kuntarto, Ninik.M. (2010). Di Balik Kerling Saatirah. Jakarta: PT Gramedia Widiasarana Indonesia.

Kurniasari, Netty Dyah. (2009). Potret Perempuan dalam Lirik Lagu. Jurnal Komunikasi, 3(1), 25-33. https:// doi.org/10.21107/ilkom.v3i1.144

Kuswidarti, Yuni. (2016). Politik Seksual dalam Novel Lemah Tanjung, Pecinan Kota Malang, dan 1998 Karya Ratna Indraswari Ibrahim. Jurnal Lakon, 5(1), 1-14. https://e-journal.unair.ac.id/ LAKON/article/view/2974/2136

Magdalene. (2018). Menjadi Perempuan. Jakarta: PT Elex Media Komputindo.

Mulawarman, Widyatmike Gede. (2014). Analisis Ideologi Gender dan Citra Perempuan dalam Kumpulan Cerpen Perempuan Kaltim Badadai Oleh 17 Perempuan Cerpenis. Borneo: Jurnal Ilmu Pendidikan LPMP Kalimantan Timur, 8(1), 87108. https://core.ac.uk/download/ pdf/275795195.pdf

Muniarti, A. Nunuk P. (2004). Getar Gender. Magelang: Yayasan Indonesia tera.

Nasri, Daratullaila. (2016). Ketidakadilan Gender terhadap Perempuan dalam Novel Padusi Karya Kabati. Madah, 7(2), 225236. $10.26499 /$ madah.v7i2.431 
Nasution, Rosramadhana. (2016). Ketertindasan Perempuan dalam Tradisi Kawin Anom: Subaltern Perempuan pada Suku Banjar dalam Perspektif Poskolonial. Jakarta: Yayasan Pustaka Obor Indonesia.

Nugroho, Bayu Aji. (2019). Perlawanan Perempuan terhadap Dominasi Patriarki dalam Novel Geni Jora Karya Abidah El Khalieqy: Kajian Feminisme Psikoanalisis Karen Horney. Jurnal Sastra Indonesia, 8 (2), 148-156. https://journal.unnes. ac.id/sju/index.php/jsi/article/ view/33719

Nugroho, Tri, dan Asti Musman. (2018). Wong Wadon: Peran dan Kedudukan Perempuan Jawa dari Zaman Klasik hingga Modern. Yogyakarta: Penerbit Pustaka Jawi.

Nurkhalifah, Dufi Intan. (2017). Pandangan Pramoedya Ananta Toer Terhadap perempuan Jawa Abad 19: Analisis Novel Gadis Pantai. Avatara, e-Jurnal Pendidikan Sejarah, 5(1), 122-136. https:// jurnalmahasiswa.unesa.ac.id/ index.php/avatara/article/ view/18358

Pradana, Gede Yoga Kharisma. 2012. Diskursus Fenomena Hamil Di Luar Nikah dalam Pertunjukan Wayang Joblar. E-Jurnal Kajian Budaya Universitas Udayana, 1(1), 11-27. https://ojs.unud. ac.id/index.php/kajian/article/ download/4643/3530

Pranowo, Yogie. (2013). Identitas Perempuan dalam Budaya Patriarkis: Sebuah Kajian Tentang Feminisme Eksistensialis Nawal El Sa'adawi dalam Novel Perempuan Di Titik Nol. Melintas Joernal, 29(1),
56-78. https://doi.org/10.26593/ mel.v29i1.266.56-78

Puspita, Yenny. (2019). Stereotip Terhadap Perempuan dalam Novel-novel Karya Abidah E1 Khalieqy: Tinjauan Sastra Feminis. Jurnal Kajian Bahasa dan Sastra (Ksatra), 1(1), 29-42. https://doi. org/10.1983/ksatra.v1i1.7

Rahmawaty, Anita. (2015). Harmoni dalam Keluarga Perempuan Karier: Upaya Mewujudkan Kesetaraan dan Keadilan Gender dalam Keluarga. Palastren: Jurnal Studi Gender, 8(1), 1-34. https://journal.iainkudus. ac.id/index.php/Palastren/article/ view/932/866

Ritzer, G dan D.J. Goodman. (2004). Teori Sosiologi Modern. Jakarta: Prenada Media.

Rizqi, Syarifatur. 2014. Tuntutan Feminisme Radikal terhadap Sistem Patriarki pada Pemikiran NH Dini dalam Karya Sastranya. Avatara, e-Jurnal Pendidikan Sejarah, 2(3), 272-285. https://jurnalmahasiswa. unesa.ac.id/index.php/avatara/ article/view/8800

Saputra, Asep Deni. (2011). Perempuan Subaltern dalam Karya Sastra Indonesia Poskolonial. Jurnal Literasi, 1(1), 16-30.https://jurnal. unej.ac.id/index.php/LIT/article/ view/649/468

Sugihastuti dan Suharto. (2016). Kritik Sastra Feminis: Teori dan Aplikasinya. Yogyakarta: Pustaka Pelajar.

Sukmawati, Lia, Bani, Sudardi, \& Dwi, Susanto. (2017). Perempuan Sasak dalam Novel Sri Rinjani Karya Eva Nourma: Kajian Feminisme. Haluan Sastra Budaya: Jurnal Ilmu-Ilmu Humaniora, 1(2), 177-190. https:// doi.org/10.20961/hsb.v1i2.15194 
Thornman, Sue. (2010). Teori Feminis dan Cultural Studies . Yogyakarta: Jalasutra.

Toer, Pramoedya Ananta. (2010). Midah (Si Manis Bergigi Emas). Jakarta: Lentara Dipantara.

Udasworo, Wening. (2018). Dari Doing ke Undoing Gender. Yogyakarta: Gadjah Mada University Press.
Umniyyah, Zahratul. (2020). Marginalisasi Perempuan: Cara Pandang Masyarakat Penganut Sistem Patriarki dalam Novel Kenanga Karya Oka Rusmini. E-prosiding Seminar Nasional Pekan Chairil Anwar, 1(1), 120129. https://jurnal.unej.ac.id/ index.php/prosiding/article/ view/19977/8728

Utumaningsing, Alifiulahtin. (2017). Gender dan Wanita Karir. Malang: UB Press. 